\title{
POWER ENERGY DISTRIBUTION AND CONSUMPTION IN NIGERIA: THE WAY FORWARD FOR SUSTAINABLE INDUSTRIAL AND COMMERCIAL DEVELOPMENT
}

\author{
A. O. Okpare ${ }^{1, *}$ and C. O. Okreghe ${ }^{2}$ \\ 1, Dept. of Elect./Elect. Engr., Delta State University, Oleh Campus, Delta State, nigeria \\ 2, Department of Elect. ANd Comp. Engineering, Edo University, IYAMHO, Edo STATE, NIGERIA \\ E-mail addresses: ${ }^{1}$ okpareao@delsu.edu.ng, ${ }^{2}$ chris.okreghe@gmail.com
}

\begin{abstract}
The wasteful, non-efficient way and manner in which the small, available power energy in Nigeria is distributed and consumed especially by residential consumers, is such that it cannot grow the country sustainably. The result is that Nigeria will continue to remain a developing economy with the associated features. This paper examines the current electricity distribution and consumption scenario in Nigeria and also discusses the myriads of problems associated with the distribution and consumption of power energy in the country. Available data and findings presented in this paper show that distribution of electricity is bedeviled with high losses and is corruption ridden while consumption is wasteful and non-efficient. The paper makes some suggestions on the way forward for Nigeria to grow sustainably. The paper concludes that unless the current electricity distribution and consumption patterns are reversed and re-patterned, industrial and commercial advancement will continue to elude the nation. The paper recommends the way forward on how to re-position the power energy sub sector of the economy so as to achieve sustainable national development.
\end{abstract}

Keywords: Power energy; Power energy consumption; industrial and commercial development; Sustainable national development; Renewable electricity

\section{INTRODUCTION}

Power energy generally referred to as electrical energy (power) or electricity is the most versatile form of energy because of its ability to be easily converted into many forms of energy like light, sound, heat, motion, e.t.c. Power energy is normally generated from conventional energy sources like fossil fuels (natural gas , coal), water power (hydro and pumped storage), biotic, nuclear fission, and so on or non-conventional (renewable) energy sources such as solar, wind, water power (tidal and waves), biofuels (biomass and biogas), geothermal, ocean thermal, or combination of both sources. At constant, in Nigeria, better part of her electricity is generated largely from natural or primary conventional energy sources such as fossil fuels (gas), hydro power, and is unfortunately, grossly inadequate. The writer in [1] gave the percentage contributions of thermal (gas) power and hydropower stations in Nigeria, which are the main sources of electricity generation, as $70-80$ thermal and $20-30$ hydroelectric. Presently, the total electricity output in Nigeria is below 5000MW and this is shown in Figure 1. Since there are high transmission and distribution losses of $8.25 \%$ and $33 \%$ respectively giving a total of $41.25 \%$, what actually gets to the end users (i.e the consumers) is usually small [1]. These losses are exclusive of transformer losses. The writers in [4] also showed that the amount of electrical energy consumed by a country at a particular instant of time largely determines the country's economic and social development 


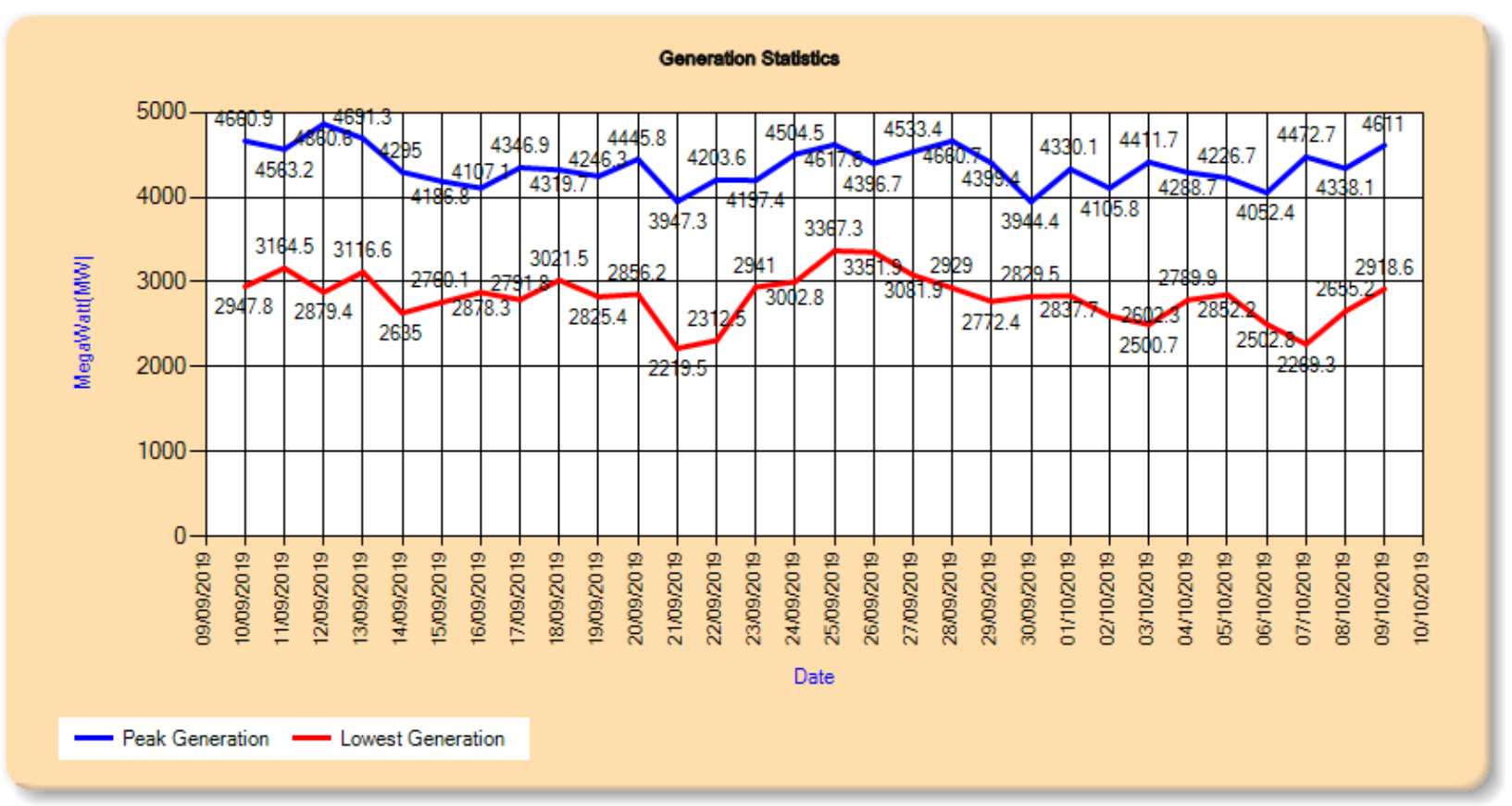

Figure 1: Power generation statistics for one month period ( $9^{\text {th }}$ Sept. to $10^{\text {th }}$ Oct., 2019) Source: [18]

In the same vein, [5] posited that Nigeria lacks sufficient electricity to power a modern economy and this deficiency is a fundamental hindrance to its prosperity. Also, studies carried out at different times by [6 - 8] established that there is proportional relationship between power energy consumed and economic development. Supporting these, [9] citing [10] posited that there is a strong correlation between the standard of living as measured by the per capita Gross Domestic Product (GDP) and the per capita power energy consumption in a country. In his lecture notes, [11] gave the relationship between per capita GDP and per capita utilization or consumption of electrical energy in Figure 2.

Electricity is usually consumed by three categories of consumers. They are residential consumers, industrial consumers, and commercial/street lighting consumers. The writers in $[1,12]$ gave the prevailing pattern of electricity consumption in Nigeria as 50: 30 : 20 for residential, industrial, and commercial/street lighting respectively. This pattern is shown in the bar chart of Figure 3.

Figures 3 and 4 showed that in Nigeria, residential electricity consumption outweighs that of industrial and commercial/street electricity consumption separately or the consumption of electricity in residential buildings is equal to or greater than the combined consumption of industrial and commercial concerns. This is a wrong pattern and is opposite of what is obtainable in the other selected countries. ${ }^{1}$ In fact, in Nigeria today, the consumption pattern is even worst in favour of residential consumers if we consider the number of residential buildings that have sprang up and are still springing up on one side, and the number of industries and commercial concerns that have folded up and are still folding up because of the cost of doing business which include the cost of electricity in running their machines and providing services. Another major reason for this wrong pattern is the non-conservative and non-efficient use of electricity by residential consumers in the country. The question central to this paper is can Nigeria develop industrially and commercially in a sustainable way with this wrong pattern of electricity consumption? This is where this paper derives its relevance. The objective of this paper is to present suggestions for correcting the present wrong power energy consumption pattern using electricity demand side management. The aim of this paper is to sustainably develop Nigeria industrially and commercially In terms of percentage, electricity consumption by the three categories of consumers in some selected countries is presented in Figure 4.

\section{CURRENT ELECTRICITY DISTRIBUTION AND CONSUMPTION SCENARIO IN NIGERIA}

Unless pragmatically addressed, the power losses presented above will be increasing and the consequence is that a small, reducing amount of 
electricity will be available for consumption. This cannot grow the country in anyway especially if Nigeria continues to largely depend on fossil sources for electricity generation. There is presently power energy poverty in Nigeria where about 60 percent of the population has no access to electricity and less than 20 percent of rural areas only have some form of electricity service coverage [13]. Corroborating this, [14] posited that in spite of Nigeria's rich oil and gas sector, $58 \%$ of the populations do not have access to electricity generated from the sector. A peep into electrical energy production and consumption by country of some African countries shows Nigeria to be second to last (Uganda). This is presented in Figure 5. The world bar represents world's average.

On a global level, extract of list of some selected countries, by rank of electric energy consumption is shown in Table 1.

Approved tariff (Reflective Multi-Year Tariff Order, MYTO) by Nigeria Electricity Regulation Council (NERC) from 2015 to 2024 as produced by Benin Electricity Distribution Company (BEDC) shows a tariff system that do not support industrial and commercial development. Extract from NERC approved tariff from 2015 to 2024 as given by BEDC is presented in table 2.

A look into the tariff regime shows that commercial and industrial concerns pay more for power consumed. The industrial and commercial outfits are supposed to have lower tariffs compared to residential consumers. This is what is practiced in developed nations. A look into the tariff regime shows that commercial and industrial concerns pay more for power consumed. The industrial and commercial outfits are supposed to have lower tariffs compared to residential consumers. This is what is practiced in developed nations.

The present estimated billing system practiced in Nigeria by the Distribution Companies like the Benin Electricity Distribution Company (BEDC) is retrogressive and does not support development in our industrial and commercial concerns. This practice is probably carried out only in Nigeria. The electric bills are not true reflections of actual electricity consumed, and therefore amount to cheating in most cases, on the part of the distribution companies. There are cases where electric meters are installed but are not read. Electricity theft in Nigeria is high. This is usually caused by illegal consumption and non-payment of electricity bills. The writer in [1] posited that for every $2 \mathrm{kWh}$ of electricity distributed, less than $1 \mathrm{kWh}$ is paid for. In
2016, [15] affirmed that the total power loss due to combined effect of illegal consumption, unpaid electricity bills, poor distribution networks is $50 \%$ of generated electricity. Also, of the over 180 million people in Nigeria, only 32 million households are connected to the National Grid and out of these only 4 million households are consumers with active electric meters [17].

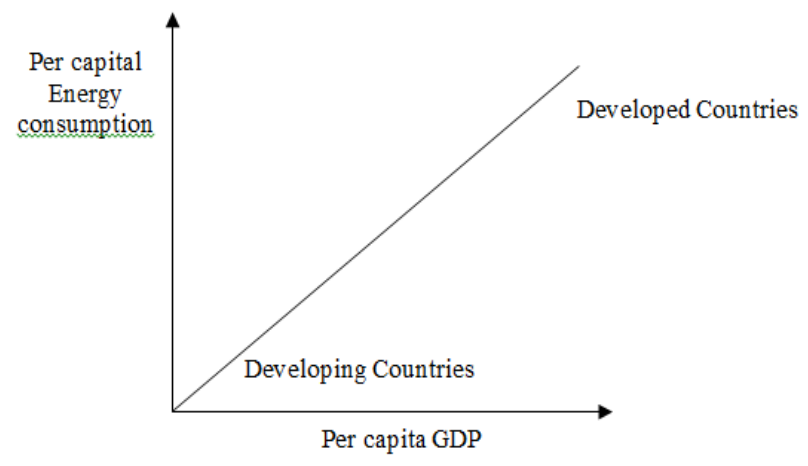

Figure 2: Relationship between per capita energy consumption and per capita GDP Source: [11]

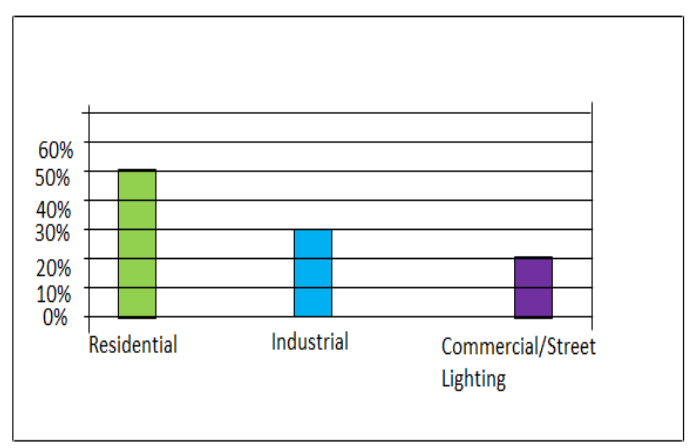

Figure 3: Electricity Consumption Pattern in Nigeria, Source: [12]

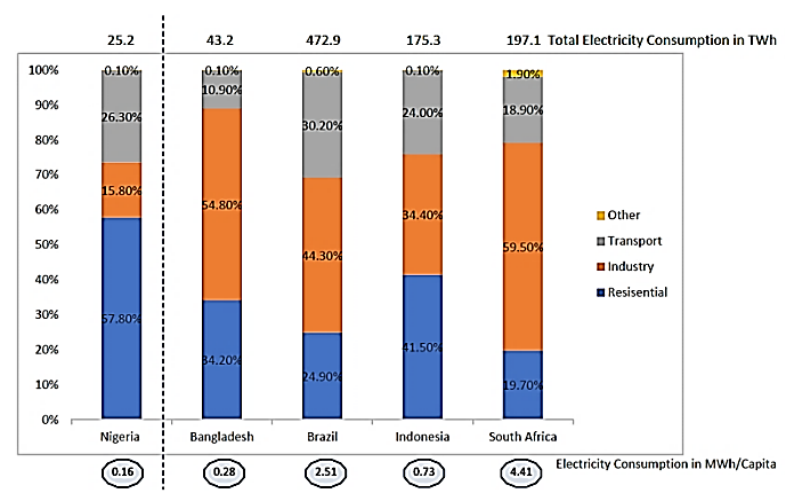

Figure 4: Residential, commercial, and industrial consumption of electricity in selected countries

Source: [1] 
The result is low revenues by the distribution companies to pay for purchased and distributed power, staff salaries, maintenance, repairs, spare parts, e.t.c. and for growth.

Low and reducing investment in distribution infrastructures by distributing companies to mitigate challenges associated with distribution of electricity to consumers. With the privatization of the power distribution network, government funding has reduced drastically. Unfortunately, the rate at which government funding was reduced was not matched with the rate at which the privatized distribution companies have invested in the distribution network [1]. There are widespread reported cases of failed transformers being replaced by consumers.

Failure on the part of the regulatory body, National Electricity Regulation Council (NERC), charged with the regulation of the power energy sector. Corruption has made NERC to compromise its role as a regulatory body.

Non efficient use of available power energy. Over $50 \%$ of electricity supplied to residential buildings is wasted as a result of intentional or non-intentional overheating, overcooling, and nonuse of energy saving electrical appliances. Low investments in renewable electricity. Prior to 2004 and up to 2008, there was no clear, available, and accessible database on renewable energy investments in Nigeria. This gives credence to high vulnerability of the power energy subsector to shocks as result of over dependence on fossil sources [13]. These shocks are still with us.

The problems in the electricity distribution system are caused by both the distribution companies and the end users i.e. the consumers. These are the joint effects of corruption and poverty.

With the combined effects of corruption and poverty presented above plaguing the power energy distribution system, what is the way forward, if Nigeria as a nation desires to be a developed nation?

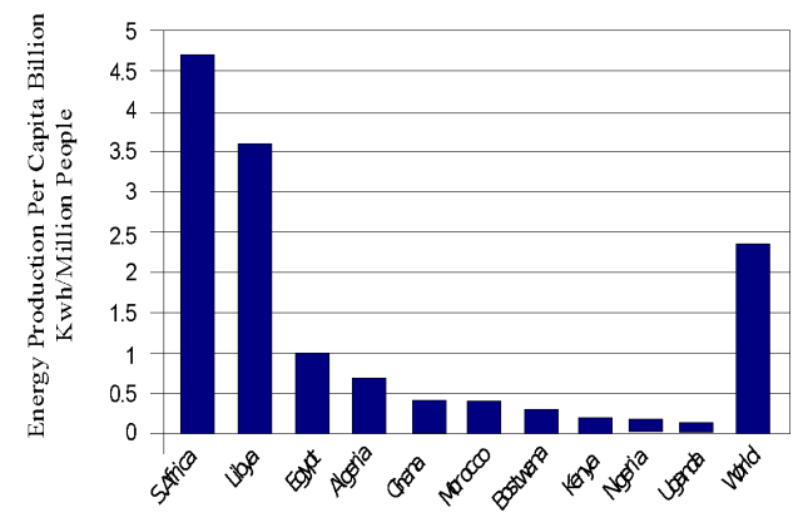

Figure 5: Electrical energy production and consumption by some African countries [18]

Table 1: Electric energy consumption of some selected countries

\begin{tabular}{lllllllll}
\hline Rank & $\begin{array}{l}\text { Countryl } \\
\text { Region }\end{array}$ & $\begin{array}{l}\text { Electricity } \\
\text { Consumption } \\
\text { (kW.h/yr) }\end{array}$ & $\begin{array}{l}\text { Year of } \\
\text { Data }\end{array}$ & Source & Population & As of & $\begin{array}{l}\text { Ave. electric } \\
\text { Energy } \\
\text { per } \\
\text { capita }\end{array}$ & $\begin{array}{l}\text { Ave. } \\
\text { per capita }\end{array}$ \\
\hline 1 & China & $6,310,000,000,000$ & 2017 & NEA & $1,403,500,365$ & 2017 & 4,475 & 510 \\
2 & United States & $3,911,000,000,000$ & 2015 EST & CIA & $323,995,528$ & 2016 & 12,071 & 1,377 \\
6 & Germany & $533,000,000,000$ & 2014 EST & CIA & $80,722,792$ & 2016 & 6,602 & 753 \\
20 & South Africa & $112,000,000,000$ & 2020 EST & CIA & $54,300,704$ & 2016 & 3,904 & 445 \\
23 & Egypt & $143,000,000,000$ & 2014 EST & CIA & $94,666,993$ & 2016 & 1,510 & 172 \\
48 & Algeria & $49,000,000,000$ & 2014 EST & CIA & $40,263,711$ & 2016 & 1,216 & 138 \\
62 & Morocco & $29,000,000,000$ & 2014 EST & CIA & $33,655,786$ & 2016 & 861 & 98 \\
68 & Nigeria & $24,000,000,000$ & 2014 EST & CIA & $186,053,386$ & 2016 & 128 & 14 \\
85 & Mozambique & $12,000,000,000$ & 2014 EST & CIA & $25,930,150$ & 2016 & 462 & 52 \\
99 & Ghana & $9,200,000,000$ & 2014 EST & CIA & $26,908,262$ & 2016 & 341 & 39 \\
104 & Zimbabwe & $8,000,000,000$ & 2014 EST & CIA & $14,546,961$ & 2016 & 549 & 62 \\
111 & Ethiopia & $6,700,000,000$ & 2014 EST & CIA & $102,374,044$ & 2016 & 65 & 7 \\
\hline
\end{tabular}

Source: [19]

Table 2: NERC approved tariff for 2015 to 2024

\begin{tabular}{lllllllllll}
\hline Class/Year & 2015 & 2016 & 2017 & 2018 & 2019 & 2020 & 2021 & 2022 & 2023 & 2024 \\
\hline R2T & 14.82 & 24.45 & 34.40 & 34.40 & 34.08 & 33.97 & 30.02 & 26.94 & 26.78 & 26.56 \\
CIT & 20.72 & 34.19 & 36.27 & 36.27 & 35.94 & 35.83 & 31.66 & 28.41 & 28.24 & 28.01 \\
DIT & 19.89 & 32.51 & 37.94 & 37.94 & 37.59 & 37.59 & 33.12 & 29.72 & 29.54 & 29.30 \\
\hline
\end{tabular}

Source: [20] 


\section{SUGGESTIONS ON THE WAY FORWARD}

Suggestions presented in this paper are predicated on the fact that the Federal Government of Nigeria will address corruption. Then naturally, poverty will be addressed.

1. Increase the present power generation from the present less than 5000MW with focus on renewable especially solar, wind, and mini-hydro power energy. The nation's Renewable Energy Master Plan developed in 2005 should be vigorously implemented in this regard.

2. Change the present wrong pattern of power energy consumption by doing the following:

a. Supply more power energy from the National grid to commercial and industrial concerns to sustain and grow them.

b. Create, encourage, and enforce the culture of efficient use of available power energy through power control and conservation by all especially residential consumers. Energy control and conservation is the practice of controlling and reducing the amount of power energy consumed through the efficient use of power energy without or minimal wastage and still achieves a similar outcome [16].

c. The Nigerian Electricity Regulatory Commission (NERC) in conjunction with the National Assembly should put in place policies that favour commercial and industrial consumers in terms of power supply

d. Electricity tariff for residential buildings, commercial outfits, and industrial concerns should be such that residential consumers pay more followed by commercial outfits and industrial concerns paying least electricity tariff as against the present practice. In this regard the current NERC approved tariff from 2015 to 2024 should be reviewed. A little wonder here is why the tariff the same across the country.

e. Adequate metering and billing system that involve the use of prepaid meters should be put in place. In this regard, every building must be metered with prepaid meter for this will encourage power energy control and conservation, which is a sine qua non for power availability.

f. Deployment of modern technologies by distribution companies to overcome power theft and other challenges as employed in countries like China. g. Reduce power wastages by consumers through the use of energy saving appliances, erecting of well cross ventilated buildings. This will entail encouraging, implementing, and enforcing the use of energy saving devices. In this regard, ban the use of incandescent bulbs and other nonenergy saving appliances. Incandescent bulbs should be retrieved from electricity consumers and replaced with energy saving bulbs by the Nigerian government as carried out in Ghana.

h. Adequate funding to sustain and grow power distribution infrastructures and also to address myriads of problems.

3. Authorities concerned should as a matter of urgency stop the erection of residential buildings that is presently indiscriminate and not well ventilated. Property developers should be encouraged to build affordable residential buildings which they will put on mortgage. Big and modern markets and shopping malls should be built to cater for buying and selling activities. In this regard, the use of small stores for buying and selling should be discouraged. This will help in easy and proper metering of buildings.

4. Ban or discourage the use of small self-electricity generating machines.

5. Encourage and implement off grid generation of power energy from renewable energy sources like solar and wind energy to serve only residential consumers and remote communities.

\section{CONCLUSION}

This paper has reviewed the current electricity distribution and consumption scenario in Nigeria and its consequences on the socioeconomic development of the country. The paper concludes that the present wasteful and non-efficient electricity consumption especially by residential consumers and the gross inadequate supply of electricity to commercial and industrial concerns, as a result of numerous problems in the distribution sub-sector occasioned by the combined effects of corruption and poverty, have negative impacts on the industrial and commercial advancement of the country. Unless the current electricity distribution and consumption patterns are reversed and re-patterned, as suggested in this paper, industrial and commercial advancement will continue to elude the nation. 


\section{RECOMMENDATION}

1. Provision of mini grids fed from solar and wind power energy should be vigorously pursued. Large power plants could also be used to feed mini grids. Mini grids systems jointly serviced from solar energy and large power plants are recommended such that a group of residential buildings will be serviced by a mini grid. The development and deployment of mini grids for provision of electricity will reduce the combined effects of corruption and poverty on electricity distribution. The longer the size of a grid, and the more consumers serviced by the grid, the more the combined effects of corruption and poverty. This will also reduce drastically transmission and distribution losses.

2. The distribution companies must be compared to massively invest and fund the distribution infrastructures so as to address challenges like power losses encountered in provision of electricity to consumers. This is where the Nigerian Electricity Regulatory Commission (NERC) and the National Assembly come in. Improvements have to be made to reduce drastically power losses from transmission through distribution to consumers' ends to the range of $4-12 \%$ [1] as obtained in developed nations. Also, modern technologies should be deployed by distribution companies to address challenges like illegal connections, electricity theft, inappropriate billing, tampered or by-passed meters, and so on. Furthermore, NERC must be proactive and not reactive in its regulatory function.

3. NERC in conjunction with the National Assembly should put in place policies that favour commercial and industrial consumers. In this regard, this paper suggests a ratio of 55: 35: 10 for industrial, commercial, and residential consumers respectively. This could be translated to mean six (6) hours, twelve (12) hours, and twenty-four (24) hours per day of power supply to residential, commercial, and industrial consumers respectively. For residential consumers, self generated electricity from renewable energy sources like solar and or wind electricity should be employed to provide power for remaining hours of the day while for commercial consumers; large power plants should be used to provide power for the remaining hours of the day. For easy implementation, there should be dedicated distribution lines to industrial and commercial concerns. To implement this, there should be industrial estates to cater for industries, large shopping malls or markets for commercial businesses, and residential estates or towns like Festac town in Lagos for residential consumers.

4. Licenses should be granted to small distribution firms to service only residential consumers. Their mini grids should be fed only from renewable energy sources like solar and/or wind electricity and large power plants.

5. Full and pragmatic implementation of the country's Renewable Energy Master Plan (REMP) drafted in 2005. This will benefit the country by restructuring the electricity industry to encourage competitive wholesale power markets, increase self-generation by end-users, unbundling of generation, transmission, and distribution of electricity and therefore create a competitive retail market. This is just one of the reasons for instituting the REMP in Nigeria.

6. To encourage commercial and industrial development, tariffs for commercial and industrial concerns should be reduced per kWh. This will reduce the cost of doing businesses in Nigeria and this will affect other things positively.

\section{REFERENCES}

[1] Ogujor, E.A.. "Two limits versus a non-limit: The settlement problem" $183^{\text {rd }}$ Inaugural Lecture, University of Benin, Benin City, Nigeria. $16^{\text {th }}$ February, 2017.

[2] Okpare, A.O., Tanno, K.O., and Oniyemofe, C.O."In search of a viable solar power development in Nigeria: A case study from selected states in the six geopolitical regions of the country", Nigerian Journal of Research and Production (NIJOREP), Vol.15, Number 1, 2009, pp $145-149$.

[3] Sobowale, D. 'Vision 2020: How Realistic?" Annual lecture delivered at the end of the year luncheon party, Government College, Ughelli Old Boys' Association, Warri Branch, Warri, Nigeria, November 15, 2012.

[4] [4] Akorede, M.F., Hizam, and Pouresmaeil. "Distributed energy resources and benefits to the environment", Renewable and Sustainable Energy Review, Vol. 14, 2010, pp $724-734$.

[5] Ofilli, A. 'Renewable energy as a sustainable energy alternative for SMEs in Nigeria." Vanguard newspaper, Wednesday, May 15, 2019.p31. 
[6] Iloeje, O.C. 'Issues in the regulation of renewable [13] Akanmu, J.O. 'Management of the downstream energy based power supply. NCERD Conference, UNN, Nigeria, 2007.

[7] Karlsson, M.K. (2005). The energy challenge for achieving the Millennium Development Goals", http://esa.un.org/un-energy, Accessed on November 15, 2019.

[8] Qurashi, M.M. and Hussain, I. “Renewable energy technologies for developing countries: Now and to 2023". Publication of the Islamic Educational, Scientific and Cultural Organization-ISESCO-1426A. H/2005.

[9] Okpare, A.O. (2004). "An assessment of renewable energy sources and their benefits to the Nigerian economy", Master degree thesis (Unpublished), School of Graduate Studies, Department of Electrical/Electronic Engineering, University of Port Harcourt, Nigeria, 2004.

[10] Davidson, I.E. and Oni, J.O. (1991). "Energy Conservation Strategies and Alternative Resources for Africa", Nigerian Journal of Renewable Energy, Vol. 2, Number 1, 1991 pp $85-88$. impact of dams operations-O-Orrbda experience and hydropower dams as a case study", $22^{\text {nd }}$ ICOLD proceedings, Barcelona, Spain, 2006, pp $517-526$.

[14] Akuru, U.B. and Okoro, O.I. 'Renewable Energy Investment in Nigeria: A review of the Renewable Energy Master Plan", Journal of Energy in Southern Africa, Vol.25, Number 3, 2014, August.

[15] Akorede, M.F., Ibrahim, O., Amuda, S.A., Otuoze, A.O., and Olufeagba, B.J. (2017). Current Status and Outlook of Renewable Energy Development in Nigeria. Nigerian Journal of Technology, Vol.36, Number.1, 2017, pp 196 - 212.

[16] Osibodu, O. 'Power Supply won't improve in next 5 years". $11^{\text {th }}$ Annual Founder's Day, University of Nigeria in Yola, November 21, 2016.

[17] Okpare, A.O., Oniyemofe, C.O. and Edward, B.A. "Ensuring power energy availability through energy control and conservation for sustainable national development in Nigeria". International Journal of Engineering Science, Vol. 2, Number 2, 2010, pp 68 -72 .

[11] Eze, O.C. (1999). 'Energy Conversion and Power [18] www.nsong.org.ng CIA Fact-book Website, Generation". Lecture notes (unpublished), Mechanical Engineering, Nnamdi Azikiwe University, Awka, 1999.

[12] Eze, O.C. (1999). 'Energy Conversion and Power Generation". Lecture notes (unpublished), Mechanical Engineering, Nnamdi Azikiwe University, Awka, 1999.

$[19]$ December, 2004.

19] http://en.wikipedia.org/wiki/List of countries by $\mathrm{e}$ lectricity consumption. Retrieved on 12th December, 2019.

[20] NERC current approved Tariff presented by Benin Electricity Distribution Company (BEDC), Benin 